\title{
Brain dopamine and serotonin transporter binding are associated with visual attention bias for food in lean men
}

Citation for published version (APA):

Koopman, K. E., Roefs, A., Elbers, D. C. E., Fliers, E., Booij, J., Serlie, M. J., \& la Fleur, S. E. (2016).

Brain dopamine and serotonin transporter binding are associated with visual attention bias for food in lean men. Psychological Medicine, 46(8), 1707-1717. https://doi.org/10.1017/S0033291716000222

Document status and date:

Published: 01/06/2016

DOI:

10.1017/S0033291716000222

Document Version:

Publisher's PDF, also known as Version of record

\section{Document license:}

Taverne

Please check the document version of this publication:

- A submitted manuscript is the version of the article upon submission and before peer-review. There can be important differences between the submitted version and the official published version of record.

People interested in the research are advised to contact the author for the final version of the publication, or visit the DOI to the publisher's website.

- The final author version and the galley proof are versions of the publication after peer review.

- The final published version features the final layout of the paper including the volume, issue and page numbers.

Link to publication

\footnotetext{
General rights rights.

- You may freely distribute the URL identifying the publication in the public portal. please follow below link for the End User Agreement:

www.umlib.nl/taverne-license

Take down policy

If you believe that this document breaches copyright please contact us at:

repository@maastrichtuniversity.nl

providing details and we will investigate your claim.
}

Copyright and moral rights for the publications made accessible in the public portal are retained by the authors and/or other copyright owners and it is a condition of accessing publications that users recognise and abide by the legal requirements associated with these

- Users may download and print one copy of any publication from the public portal for the purpose of private study or research.

- You may not further distribute the material or use it for any profit-making activity or commercial gain

If the publication is distributed under the terms of Article $25 \mathrm{fa}$ of the Dutch Copyright Act, indicated by the "Taverne" license above, 


\title{
Brain dopamine and serotonin transporter binding are associated with visual attention bias for food in lean men
}

\author{
K. E. Koopman ${ }^{1}$, A. Roefs $^{2}$, D. C. E. Elbers ${ }^{1}$, E. Fliers ${ }^{1}$, J. Booij ${ }^{3}$, M. J. Serlie ${ }^{1}+$ and S. E. la Fleur ${ }^{1 *}+$ \\ ${ }^{1}$ Department of Endocrinology \& Metabolism, Academic Medical Center Amsterdam, University of Amsterdam, The Netherlands \\ ${ }^{2}$ Faculty of Psychology \& Neuroscience, Maastricht University, Maastricht, The Netherlands \\ ${ }^{3}$ Department of Nuclear Medicine, Academic Medical Center Amsterdam, University of Amsterdam, The Netherlands
}

Background. In rodents, the striatal dopamine (DA) system and the (hypo)thalamic serotonin (5-HT) system are involved in the regulation of feeding behavior. In lean humans, little is known about the relationship between these brain neurotransmitter systems and feeding. We studied the relationship between striatal DA transporters (DAT) and diencephalic 5-HT transporters (SERT), behavioral tasks and questionnaires, and food intake.

Method. We measured striatal DAT and diencephalic SERT binding with $\left[{ }^{123}\right.$ I]FP-CIT SPECT in 36 lean male subjects. Visual attention bias for food (detection speed and distraction time) and degree of impulsivity were measured using response-latency-based computer tasks. Craving and emotional eating were assessed with questionnaires and ratings of hunger by means of VAS scores. Food intake was assessed through a self-reported online diet journal.

Results. Striatal DAT and diencephalic SERT binding negatively correlated with food detection speed $(p=0.008, r=-0.50$ and $p=0.002, r=-0.57$, respectively), but not with food distraction time, ratings of hunger, craving or impulsivity. Striatal DAT and diencephalic SERT binding did not correlate with free choice food intake, whereas food detection speed positively correlated with total caloric intake $(p=0.001, r=0.60)$, protein intake $(p=0.01, r=0.44)$, carbohydrate intake $(p=0.03, r=0.39)$ and fat intake $(p=0.06, r=0.35)$.

Conclusions. These results indicate a role for the central 5-HT and DA system in the regulation of visual attention bias for food, which contributes to the motivation to eat, in non-obese, healthy humans. In addition, this study confirms that food detection speed, measured with the latency-based computer task, positively correlates with total food and macronutrient intake.

Received 15 December 2015; Revised 18 January 2016; Accepted 18 January 2016; First published online 17 March 2016

Key words: Dopamine, food intake, lean man, serotonin, visual attention bias.

\section{Introduction}

The amount of food we consume is determined by hunger and satiety signals as well as by the accessibility and the rewarding properties of food and a person's motivation to obtain food. The brain plays a major role in food intake and one of the neurotransmitters involved is dopamine (DA), particularly striatal DA. Although in the literature striatal DA is often used as a surrogate for hedonism, the striatal DA system is in fact related to the motivation to seek food and not so much to the hedonic value of the reward (Kelley et al. 2005; Berridge, 2007). Rodent studies have

\footnotetext{
* Address for correspondence: Dr S. E. la Fleur, Department of Endocrinology \& Metabolism, Academic Medical Center, University of Amsterdam, Meibergdeef 9, 1105 AZ, Amsterdam, The Netherlands.

(Email: s.e.lafleur@amc.uva.nl)

t These authors contributed equally to this work.
}

shown a relationship between food-related motivational behavior and the striatal DA system. Stimulating DA release with amphetamine in rats specifically amplified incentive salience for a food reward but not hedonic 'liking' (Tindell et al. 2005), and motivation to obtain a food reward is reduced when DA antagonists are administered in the striatum of rats (Baldo et al. 2002). Moreover, food itself, as well as the sight or smell of food, serve as stimuli for striatal DA release (Small et al. 2003; Berridge, 2009). The relationship between food stimuli that enhance motivated behavior and the striatal DA system in humans, however, has not been investigated in depth. Theoretically, motivation elicited by stimuli is thought to be related to the attention-grabbing properties of these stimuli (Field \& Cox, 2008; Berridge, 2009; Field et al. 2009) and food attention bias has been related to motivation for food (craving) but also to 'worry about food' in the context of anorexia nervosa (Werthmann et al. 2014a). To measure attention for a food stimulus in humans, 
measurements of the detection speed or distraction time when a food stimulus is provided (i.e. visual attention) with validated computerized tasks (Derryberry, 1989) is used. If a person detects a food item faster than a non-food item, he or she has a biased attention for food.

Although studies in rodents clearly demonstrate a relationship between motivation to obtain food and the striatal DA system, direct evidence for a relationship between visual attention bias for food and the striatal DA system in healthy, lean humans is currently unavailable. A faster response to visual food stimuli (Castellanos et al. 2009; Tetley et al. 2009; Nijs et al. 2010) and decreased striatal DA $D_{2 / 3}$ receptor binding (Wang et al. 2001; de Weijer et al. 2011; van de Giessen et al. 2014) found in obese compared to lean humans points towards a direct relationship between DA and visual attention bias for food. Presynaptically located dopamine transporters (DATs) are important regulators of available extracellular DA and thereby of DA signaling (German et al. 2015). As the striatal DA system relates to incentive salience for all kinds of food (Tindell et al. 2005), we hypothesized that striatal DAT binding is related to visual attention bias for food in general.

In addition to DA being involved in motivational behavior to obtain food, the neurotransmitter serotonin (5-hydroxytryptamine; 5-HT) plays a role in hunger and satiety, as it is released during the meal to reduce intake and terminate the meal (Lam \& Heisler, 2007). 5-HT is produced in the raphe nuclei and broadly transported throughout the brain; dense projections are found in the thalamus and hypothalamus (Lam \& Heisler, 2007). Serotonergic drugs such as the $5-\mathrm{HT}_{2 \mathrm{C}}$ receptor agonist lorcaserin, currently in use as antiobesity drug, suppress hunger and increase satiety in obese but also in lean humans (Halford et al. 2007), resulting in significant weight loss (Smith et al. 2010). Inversely when central 5-HT is depleted, rodents demonstrate uncontrollable hyperphagia (Breisch et al. 1976; Saller \& Stricker, 1976; Waldbillig et al. 1981). In a hungry state (i.e. fasted) when 5-HT levels are low (Haider \& Haleem, 2000), obese and lean subjects show increased visual attention bias for food pictures (Castellanos et al. 2009). However, it has not been investigated yet whether there is a direct association between visual attention bias for food and the (hypo) thalamic 5-HT system in the fasting state in humans. Like DAT, serotonin transporters (SERTs) are presynaptically located regulators of extracellular 5-HT levels (Daws \& Gould, 2011). SERT binding is reduced in binge-eating disorder, a condition associated with increased impulsivity (Kuikka et al. 2001; Schag et al. 2013) but a direct relationship between 5-HT and impulsivity has not been demonstrated. We hypothesized that SERT binding in the diencephalon, an area that contains the hypothalamus, thalamus and pineal gland, is negatively associated with impulsivity in lean humans.

Although it is a general assumption that an increased visual attention bias for food results in increased food intake in daily life, only few laboratory studies investigated this topic (Nijs et al. 2010; Werthmann et al. 2013, 2014b; Hardman et al. 2014). Werthmann et al. (2014a), for example, showed that a high visual attention bias for chocolate was related to higher chocolate intake. We hypothesized that visual attention bias for food in general is positively associated with total food intake. To test the aforementioned hypotheses we measured striatal DAT and diencephalic SERT binding with $\left[{ }^{123} \mathrm{I}\right] \mathrm{FP}-\mathrm{CIT}$ single photon emission computed tomography (SPECT) and correlated these outcomes with free choice self-reported food intake, visual attention bias for food and impulsivity measured with a latency-based computerized tasks and impulsivity and craving measured with questionnaires.

\section{Materials and method}

The subjects described in this study were included in a hypercaloric diet intervention trial. The effects of the hypercaloric diet intervention on metabolism, liver fat and diencephalic SERT binding have been published previously (Koopman et al. 2013, 2014a). In this paper we present the baseline data, all measurements were performed before the start of the hypercaloric diets.

\section{Study population}

A total of 36 healthy, male subjects with a mean age of $22.2 \pm 2.5$ years and a mean body mass index (BMI) of $22.3 \pm 1.4 \mathrm{~kg} / \mathrm{m}^{2}$ (range 19.6-24.9 kg/m²) were included in the current baseline data analyses. Exclusion criteria were a history of psychological or psychiatric disorders, eating disorders assessed with the Eating Disorders Examination Questionnaire (EDE-Q; Fairburn \& Beglin, 1994; Luce \& Crowther, 1999), substance and alcohol abuse, unstable weight, any medical condition, performance of excessive sports, shift work and use of any medication. The study was approved by the institutional review board of the AMC, Amsterdam. Written informed consent was received from all participants prior to the start of study participation. The authors assert that all procedures contributing to this work comply with the ethical standards of the relevant national and institutional committees on human experimentation and with the Helsinki Declaration of 1975, as revised in 2008. 


\section{Measurements and calculations}

\section{Imaging of DAT and SERT}

After an overnight fast subjects underwent SPECT imaging after intravenous administration of $115 \mathrm{MBq}$ $\left[{ }^{123} \mathrm{I}\right] \mathrm{FP}-\mathrm{CIT}$ (range $110-120 \mathrm{MBq}$; specific activity $>750 \mathrm{MBq} / \mathrm{nmol}$; radiochemical purity $>98 \%$, produced according to GMP criteria at GE Healthcare, The Netherlands) measuring SERT binding in the diencephalon $2 \mathrm{~h}$ and DAT binding in the striatum $3 \mathrm{~h}$ after injection, the optimal time points for visualizing SERTs and DATs with [ ${ }^{123}$ I]FP-CIT SPECT, respectively (Booij et al. 1999; Koopman et al. 2012). Each participant was pretreated with potassium iodide to block thyroid uptake of free radioactive iodide. SPECT imaging was performed using a 12-detector, single-slice brain-dedicated scanner (Neurofocus Inc., USA), using an acquisition protocol as described earlier with slight modifications (interslice distance $5 \mathrm{~mm}$, acquisition time $210 \mathrm{~s}$ per slice) (Booij et al. 1999). All scans were reconstructed in $3 \mathrm{D}$ and corrected for attenuation. For quantification, a region-of-interest (ROI) analysis to determine specific binding activity in the diencephalon and striatum was performed by a well-trained researcher and confirmed by a second analyst as described earlier (Booij et al. 1999). Briefly, the four consecutive slices with the highest binding were selected in the diencephalon (including hypothalamus/thalamus) to assess binding to SERT and in the striatum to assess binding to DAT. Activity in the cerebellum (three consecutive slices), excluding the SERT-rich vermis, was assumed to represent nondisplaceable activity (non-specific binding and free radioactivity). Since the mean activity in a given volume is dependent of the number of slices included, we analyzed monoamine transporter availability in a similar amount of slices in each subject. We therefore standardized on four consecutive slices for the striatum and diencephalon and three slices for the cerebellum as this was the minimum amount of slices that was available in all subjects. A specific-to-non-specific binding ratio (SNS-BR) was calculated as

$\frac{\text { ROI binding - cerebellar binding }}{\text { cerebellar binding }}$.

The SNS-BR was used as the outcome measure. Due to a technical problem with the SPECT scanner, scans of six subjects had to be excluded from the analyses, therefore data on DAT and SERT binding were available for 30 subjects.

\section{Computerized tasks and questionnaires}

Tasks and questionnaires were selected to assess functions associated with the brain 5-HT and DA systems and were performed and completed after an overnight fast of approximately $12 \mathrm{~h}$, on the same day as the SPECT scans were acquired.

Delay Discounting Task. A computerized task for assessment of impulsive decision making. Subjects choose between a smaller immediate reward (money) or a larger future reward. The future reward ranged from 2 weeks to 10 years from now. When subjects are inclined to choose the smaller, immediate amount of money over large, delayed money, they are characterized by greater levels of impulsivity. A detailed description of this task has been published previously (Wittmann et al. 2007). Behavioral performance was analyzed by plotting the indifference points (the points where immediate and delayed reward were equally valued) at different time points and the area under the curve was used as a behavioral outcome (Myerson et al. 2001).

Visual Search Task. The computerized odd-one-out version of this task requests the participant to decide as quickly as possible whether a matrix of 20 visual stimuli consists of pictures from just one category or whether there is one picture from a different category (odd-one-out). Each trial started with a brief tone, followed by a fixation cross $(500 \mathrm{~ms})$. Then a $5 \times 4$ matrix containing 20 visual stimuli was presented. Participants initially completed 12 practice trials (with pictures of tools and clocks) followed by 154 experiment trials. The matrices were composed of pictures of food (low-caloric or high-caloric products) and pictures of neutral, non-food items (bags and balls). Food items were selected on caloric density. Mean caloric density was $40 \pm 18 \mathrm{kcal} / 100 \mathrm{~g}$ for lowcaloric products and $402 \pm 112 \mathrm{kcal} / 100 \mathrm{~g}$ for highcaloric products. The food- and non-food items were matched on color and shape. Examples of the matrices and a full list of the food items are presented in the Supplementary material (Fig. S1 and Table S1). Of the experiment trials, 42 were one-category matrices and 114 were odd-one-out matrices. The task lasted approximately $15 \mathrm{~min}$ and was split into two blocks of trials, separated by a brief break. Participants were instructed to respond as quickly and as accurately as possible, and to press the right key in case of an odd-one-out (one picture in a category different from the other 19 pictures), and the left key in case of no odd-one-out (20 pictures in the same category). The matrix remained on screen until the participant responded or for a maximum of $20 \mathrm{~s}$, then a new trial started. We used six 'odd-one-out' matrices: one highcaloric food target among 19 neutral items (bags) $(n=$ $19)$, one low-caloric food target among 19 neutral items (bags) $(n=19)$, one neutral target (ball) among 19 other neutral items (bags) $(n=19)$, one neutral target (bag) 
among 19 high-caloric food items $(n=19)$, one neutral target (bag) among 19 low-caloric food items $(n=19)$, one neutral target (bag) among 19 other neutral items (balls) $(n=19)$. The visual search task was programmed using E-prime software (Eprime 1.0; Psychology Software Tools Inc., USA). We assessed both reaction time (RT) and accuracy. Trials with an inaccurate response were not included in the analyses. RT outliers were excluded from the analyses if $<200 \mathrm{~ms},>2000 \mathrm{~ms}$ or $>3$ S.D. above each participant's mean. Food detection speed and food distraction scores were calculated for each participant. Food detection speed was calculated by subtracting the average response latency on food-target-trials from the average response latency on neutral-target trials. So, a higher food detection speed score indicates a faster detection of food items than of neutral items. The food distraction score was computed by subtracting the average response latency on neutral-distractor trials from the average response latency on food-distractor trials. So, a higher food distraction score indicates more distraction by food items than by neutral items.

Dutch Eating Behavior Questionnaire (DEBQ). A 33-item self-report for assessment of restrained, emotional and external eating behavior (van Strien et al. 1986).

Barratt Impulsiveness Scale. The Dutch 30-item version of this scale (BIS-11), scored on a 4-point scale, was used for assessment of self-reported impulsiveness (Patton et al. 1995).

General Food Craving Questionnaire-Trait (G-FCQ-T). A four-factor, 21-item questionnaire to assess general trait food cravings (Nijs et al. 2007).

Hunger and Appetite. Assessed with $100 \mathrm{~mm}$ visual analog scales (VAS) anchored at each end with descriptive extremes (e.g. extremely hungry - not hungry at all). Subjects were required to mark a point on the scale within the anchored points, which related to how hungry they felt.

\section{Food intake}

We assessed food intake with an online diet journal designed by the Dutch Nutrition Centre (eetmeter.voedingscentrum.nl). Participants reported their free choice food intake at this website during 7 days prior to the measurements. Reported intake was compared to the eucaloric need to assess eventual underreporting. Eucaloric need was calculated as $1.4 \times$ resting energy expenditure (REE). REE was measured using indirect calorimetry as described previously (Koopman et al. 2014a). The 40\% caloric need surplus (on top of REE) represents expected caloric need for physical activity. In addition we measured body weight before and after this week, which had to be stable to validate that the reported intake was eucaloric and weight-maintaining. Mean difference between reported intake and calculated caloric need was $236.7 \mathrm{kcal} /$ day ( $8 \%$ of expected intake). We suspected underreporting of free-choice food intake in three subjects (reported intake about $1000 \mathrm{kcal}$ lower than expected based on energy expenditure measurements, difference in expected and reported intake $>2.5$ S.D. below the mean). Therefore food intake data of these two subjects were excluded and analyses on food intake were performed on data of 33 subjects.

\section{Statistics}

Statistical analyses were performed using SPSS v. 20.0 (IBM Corp., USA). Data were tested for normality. The overall primary hypothesis was that both diencephalic SERT and striatal DAT binding are associated with, visual attention bias for food in general and that visual attention bias for food is associated with free-choice total caloric intake. To evaluate this we first performed Pearson correlations to detect any individual correlations between study parameters. We subsequently performed forward multivariate analysis to determine independent predictors of food intake. We used the rule that the maximum number of variables was no more than $10 \%$ of the analysed number of observations, which meant that the maximum number of simultaneously entered variables was 3 . For the multivariate analysis we chose as predictor variables: (1) BMI; (2) visual attention bias and (3) SERT and DAT binding ratios (SNS-BR). There was multicollinearity between diencephalic SERT and striatal DAT binding; these parameters could not be analysed in the same model. Therefore we designed two models with BMI, visual attention bias and SERT or DAT binding ratios (SNS-BR), respectively. Effects were considered significant when was $p<0.05$ and a trend when $p<0.1$.

\section{Results}

Baseline characteristics of the study participants and mean \pm S.D. of all outcome values are presented in Table 1. Statistical outcomes of all univariate analyses are presented in Table 2 .

\section{Correlations between visual attention bias for food and reported food intake}

As hypothesized, food detection speed was positively associated with total caloric intake (Table 2, Fig. 1a), indicating that a faster detection of food stimuli was related to higher food intake. Reported carbohydrate 
Table 1. Characteristics

\begin{tabular}{|c|c|c|}
\hline & & $N^{\mathrm{a}}$ \\
\hline Age (years) & $22.1 \pm 2.5$ & 36 \\
\hline BMI $\left(\mathrm{kg} / \mathrm{m}^{2}\right)$ & $22.3 \pm 1.4$ & 36 \\
\hline Weight (kg) & $79.1 \pm 7.5$ & 36 \\
\hline $\operatorname{REE}(\mathrm{kcal} / \mathrm{kg})$ & $23.8 \pm 2.3$ & 36 \\
\hline \multicolumn{3}{|l|}{ Brain SERT and DAT binding } \\
\hline Striatal DAT binding (SNS-BR) & $5.12 \pm 1.21$ & 30 \\
\hline Diencephalic SERT binding (SNS-BR) & $0.58 \pm 0.21$ & 30 \\
\hline \multicolumn{3}{|l|}{ Food intake } \\
\hline Reported total caloric intake (kcal/day) & $2525 \pm 282$ & 33 \\
\hline Expected caloric intake (kcal/day) ${ }^{\mathrm{b}}$ & $2733 \pm 175$ & 35 \\
\hline Reported carbohydrate intake (g/day) & $289 \pm 49$ & 33 \\
\hline $\begin{array}{l}\text { Carbohydrate intake (\% of total caloric } \\
\text { intake) }\end{array}$ & $46 \pm 6$ & 33 \\
\hline Reported fat intake (g/day) & $92 \pm 17$ & 33 \\
\hline Fat intake (\% of total caloric intake) & $33 \pm 5$ & 33 \\
\hline Reported protein intake (g/day) & $98 \pm 17$ & 33 \\
\hline Protein intake (\% of total caloric intake) & $16 \pm 2$ & 33 \\
\hline \multicolumn{3}{|l|}{ Visual attention $^{c}$} \\
\hline Detection speed food in general (RT in ms) & $1642 \pm 496$ & 33 \\
\hline Detection speed high caloric food (RT in ms) & $1670 \pm 539$ & 33 \\
\hline Detection speed low caloric food ( $\mathrm{RT}$ in $\mathrm{ms}$ ) & $1613 \pm 485$ & 33 \\
\hline Detection speed neutral items (RT in ms) & $1838 \pm 672$ & 33 \\
\hline Distraction time food in general ( $\mathrm{RT}$ in $\mathrm{ms}$ ) & $1568 \pm 412$ & 33 \\
\hline Distraction time high caloric food ( $\mathrm{RT}$ in $\mathrm{ms}$ ) & $1657 \pm 506$ & 33 \\
\hline Distraction time low caloric food ( $\mathrm{RT}$ in $\mathrm{ms}$ ) & $1479 \pm 317$ & 33 \\
\hline Distraction time neutral items (RT in ms) & $1670 \pm 585$ & 33 \\
\hline \multicolumn{3}{|l|}{ Other tasks and questionnaires } \\
\hline Delay discounting (AUC of IP) & $0.57 \pm 0.22$ & 33 \\
\hline BIS-11 total score (points) & $67.2 \pm 6.1$ & 36 \\
\hline G-FCQ-T total score (points) & $44.4 \pm 12.2$ & 36 \\
\hline DEBQ emotional eating (points) & $12.9 \pm 3.2$ & 36 \\
\hline DEBQ restraint eating (points) & $30.1 \pm 4.1$ & 36 \\
\hline DEBQ external eating (points) & $17.9 \pm 6.2$ & 36 \\
\hline VAS Hunger (0-100 scale) & $48.3 \pm 22.7$ & 36 \\
\hline VAS Satiety (0-100 scale) & $56.9 \pm 22.8$ & 36 \\
\hline
\end{tabular}

BMI, body mass index; REE, resting energy expenditure; SERT, serotonin transporter; DAT, dopamine transporter; SNS-BR, specific to non-specific binding ratio; $\mathrm{RT}$, reaction time in milliseconds; AUC of IP, area under the curve of the indifference point graph; BIS, Barratt impulsiveness scale; G-FCQ-T, General Food Craving Questionnaire - trait; DEBQ, Dutch Eating Behavior Questionnaire; VAS, visual analog scale.

Data presented as mean \pm S.D. Measures were performed in fasting condition. Caloric and macronutrient intake presented as the average daily intake based on the weekly intake.

${ }^{a}$ Due to exclusion of outliers and missing data, $N$ is variable per outcome measure.

${ }^{\mathrm{b}}$ Expected daily caloric intake is calculated as $1.4 \times \mathrm{REE}$.

${ }^{\mathrm{c}}$ Absolute RTs per category not corrected for RT for a neutral target are presented.

and protein intake were positively associated with food detection speed (Table 2, Fig. 1b,c), whereas reported fat intake tended to be positively associated with food detection speed (Table 2, Fig. 1d). Food distraction time was not associated with reported total caloric intake or reported intake of any specific macronutrients (Table 2).

\section{Correlations with brain SERT and DAT binding}

Striatal DAT binding ratios (SNS-BR) were negatively associated with food detection speed, as were diencephalic SERT binding ratios (Table 2, Fig. 2a,b), showing that a faster detection of food stimuli was related to reduced DAT and SERT binding. Neither striatal DAT binding ratios nor diencephalic SERT binding ratios were associated with food distraction time (Table 2). In addition, striatal DAT and diencephalic SERT binding ratios were not associated with reported total caloric intake or reported intake of any specific macronutrient (Table 2). Striatal DAT binding ratios correlated positively with diencephalic SERT binding (Table 2). Finally, striatal DAT binding and diencephalic SERT binding were both associated with REE but not with BMI or outcomes of the questionnaires (Table 2).

\section{Multivariate prediction model for food intake}

To detect independent associations with reported food intake, we performed multivariate regression analyses using two models: one with diencephalic SERT binding ratios, food detection speed and BMI as variables (model 1), and one with striatal DAT binding ratios, food detection speed and BMI as variables (model 2), with SERT and DAT binding as dependent variables, thereby resulting in a total of two regression models. Total variance explaining caloric intake was $43 \%$ in model $1(p=0.004)$ and $45 \%$ in model $2(p=0.003)$. Food detection speed was the only independent predictor of total caloric intake in both models (model 1 $p=0.003$, model $2 p<0.001$ ). Reported fat and carbohydrate intake was not significantly predicted by model 1 $(r=0.43, p=0.20)$ and $(r=0.41, p=0.22)$, respectively or model $2(r=0.41, p=0.22)$ and $(r=0.41, p=0.22)$, respectively. Reported protein intake was not significantly predicted by model $1(r=0.49, p=0.09)$, but explained a total variance of $45 \%$ by model $2(p=$ $0.003)$. Striatal DAT binding ratios $(p=0.007)$ and food detection speed $(p<0.001)$ were both independent predictors of reported protein intake.

\section{Discussion}

We show that striatal DAT binding and diencephalic SERT binding negatively correlate with detection speed of visual food stimuli in lean, healthy men on a eucaloric free-choice diet. In addition, detection speed of visual food stimuli correlated positively 
Table 2. Univariate linear regression analysis

\begin{tabular}{|c|c|c|c|c|c|c|c|c|c|c|c|c|c|c|c|}
\hline & \multicolumn{3}{|c|}{$\begin{array}{l}\text { Striatal DAT } \\
\text { binding }\end{array}$} & \multicolumn{3}{|c|}{$\begin{array}{l}\text { Diencephalic } \\
\text { SERT binding }\end{array}$} & \multicolumn{3}{|c|}{$\begin{array}{l}\text { Food detection } \\
\text { speed }\end{array}$} & \multicolumn{3}{|c|}{$\begin{array}{l}\text { Food distraction } \\
\text { time }\end{array}$} & \multicolumn{3}{|c|}{$\begin{array}{l}\text { Reported total } \\
\text { caloric intake }\end{array}$} \\
\hline & $r$ & $r^{2}$ & $P$ & $r$ & $r^{2}$ & $P$ & $r$ & $r^{2}$ & $P$ & $r$ & $r^{2}$ & $P$ & $r$ & $r^{2}$ & $P$ \\
\hline BMI $\left(\mathrm{kg} / \mathrm{m}^{2}\right)$ & 0.34 & 0.12 & 0.07 & 0.23 & 0.05 & 0.23 & 0.08 & 0.01 & 0.66 & 0.29 & 0.08 & 0.11 & 0.05 & 0.00 & 0.78 \\
\hline REE (kcal/kg) & 0.42 & 0.17 & 0.02 & 0.37 & 0.14 & 0.05 & 0.24 & 0.06 & 0.19 & 0.03 & 0.00 & 0.89 & 0.01 & 0.00 & 0.98 \\
\hline $\begin{array}{l}\text { Total caloric intake } \\
\text { (kcal/day) }\end{array}$ & 0.21 & 0.05 & 0.26 & 0.28 & 0.08 & 0.13 & 0.60 & 0.36 & $<0.001$ & 0.21 & 0.05 & 0.26 & $x$ & $x$ & $x$ \\
\hline $\begin{array}{l}\text { Carbohydrate intake } \\
\text { (g/day) }\end{array}$ & 0.12 & 0.01 & 0.55 & 0.20 & 0.04 & 0.29 & 0.39 & 0.15 & 0.03 & 0.17 & 0.03 & 0.36 & 0.59 & 0.34 & $<0.001$ \\
\hline Fat intake (g/day) & 0.26 & 0.07 & 0.17 & 0.15 & 0.02 & 0.42 & 0.35 & 0.12 & 0.06 & 0.14 & 0.02 & 0.47 & 0.68 & 0.46 & $<0.001$ \\
\hline Protein intake (g/day) & 0.11 & 0.01 & 0.56 & 022 & 0.05 & 0.25 & 0.44 & 0.20 & 0.01 & 0.34 & 0.12 & 0.07 & 0.64 & 0.41 & $<0.001$ \\
\hline $\begin{array}{l}\text { Food detection speed } \\
(\mathrm{ms})\end{array}$ & 0.50 & 0.25 & 0.008 & 0.57 & 0.32 & 0.002 & $x$ & $x$ & $x$ & $x$ & $x$ & $x$ & 0.60 & 0.36 & $<0.001$ \\
\hline $\begin{array}{l}\text { Food distraction time } \\
(\mathrm{ms})\end{array}$ & 0.12 & 0.02 & 0.55 & 0.00 & 0.00 & 0.99 & $x$ & $x$ & $x$ & $x$ & $x$ & $x$ & 0.21 & 0.05 & 0.26 \\
\hline $\begin{array}{l}\text { Delay discounting } \\
\text { (pts) }\end{array}$ & 0.07 & 0.01 & 0.71 & 0.38 & 0.14 & 0.07 & 0.28 & 0.08 & 0.12 & 0.13 & 0.02 & 0.46 & 0.09 & 0.01 & 0.61 \\
\hline BIS (pts) & 0.06 & 0.00 & 0.76 & 0.17 & 0.03 & 0.38 & 0.08 & 0.00 & 0.65 & 0.09 & 0.01 & 0.62 & 0.02 & 0.00 & 0.89 \\
\hline $\begin{array}{l}\text { Craving } \\
\text { (G-FCQ-T, pts) }\end{array}$ & 0.14 & 0.02 & 0.48 & 0.13 & 0.02 & 0.49 & 0.33 & 0.11 & 0.06 & 0.32 & 0.10 & 0.07 & 0.14 & 0.02 & 0.44 \\
\hline $\begin{array}{l}\text { DEBQ emotional } \\
\text { eating (pts) }\end{array}$ & 0.04 & 0.00 & 0.82 & 0.13 & 0.02 & 0.49 & 0.34 & 0.12 & 0.08 & 0.56 & 0.31 & 0.003 & 0.16 & 0.03 & 0.39 \\
\hline $\begin{array}{l}\text { DEBQ external eating } \\
\text { (pts) }\end{array}$ & 0.00 & 0.00 & 1.00 & 0.03 & 0.00 & 0.89 & 0.14 & 0.02 & 0.50 & 0.15 & 0.02 & 0.45 & 0.24 & 0.06 & 0.21 \\
\hline $\begin{array}{l}\text { DEBQ restraint eating } \\
\text { (pts) }\end{array}$ & 0.15 & 0.02 & 0.44 & 0.04 & 0.00 & 0.83 & 0.09 & 0.00 & 0.67 & 0.10 & 0.01 & 0.62 & 0.01 & 0.00 & 0.97 \\
\hline $\begin{array}{l}\text { VAS Hunger score } \\
\text { (pts) }\end{array}$ & 0.36 & 0.13 & 0.05 & 0.25 & 0.06 & 0.18 & 0.06 & 0.00 & 0.75 & 0.11 & 0.01 & 0.53 & 0.19 & 0.04 & 0.29 \\
\hline $\begin{array}{l}\text { VAS Appetite score } \\
\text { (pts) }\end{array}$ & 0.29 & 0.09 & 0.12 & 0.21 & 0.05 & 0.26 & 0.23 & 0.05 & 0.21 & 0.07 & 0.00 & 0.72 & 0.05 & 0.00 & 0.79 \\
\hline $\begin{array}{l}\text { Striatal DAT binding } \\
\text { (SNS-BR) }\end{array}$ & $x$ & $x$ & $x$ & 0.48 & 0.23 & 0.008 & 0.50 & 0.25 & 0.008 & 0.12 & 0.02 & 0.55 & 0.21 & 0.05 & 0.26 \\
\hline $\begin{array}{l}\text { Dienceph SERT } \\
\text { binding (SNS-BR) }\end{array}$ & 0.48 & 0.23 & 0.008 & $x$ & $x$ & $x$ & 0.57 & 0.32 & 0.002 & 0.00 & 0.00 & 0.99 & 0.28 & 0.08 & 0.13 \\
\hline
\end{tabular}

BMI, Body mass index; REE, resting energy expenditure; BIS, Barratt Impulsiveness Scale; G-FCQ-T, General Food Craving Questionnaire - trait; DEBQ, Dutch Eating Behavior Questionnaire; VAS, visual analog scale; DAT, dopamine transporter; SNS-BR, specific to non-specific binding ratio; SERT, serotonin transporter.

with total food and individual macronutrient intake, whereas striatal DAT and diencephalic SERT binding did not independently correlate with food intake. Taken together, our findings point to a physiological role for DA and 5-HT signaling in attention for food, whereas attention for food is involved in the total food intake.

To our knowledge, we are the first to report a direct negative relationship between striatal DAT binding and visual attention bias for food, as well as between diencephalic SERT binding and visual attention bias for food in lean humans. Our results suggest that in a healthy feeding condition, visual attention bias for food and subsequent food intake could well be regulated by the striatal
DA system and the diencephalic 5-HT system; in other words these systems may play a role in the physiological, homeostatic regulation of food intake.

Whether these findings in normal-weight individuals can be extrapolated to people with higher BMI remains to be determined. Of interest, central SERT binding was negatively correlated to BMI in a sample of lean and obese humans (Erritzoe et al. 2010) and SERT protein in the infundibular nucleus of the hypothalamus was reduced in obese humans (Borgers et al. 2014). We here show a negative correlation between SERT and visual attention bias for food, and thus the lower SERT in obesity might explain a higher visual attention bias for food in obese compared to lean 
(a)

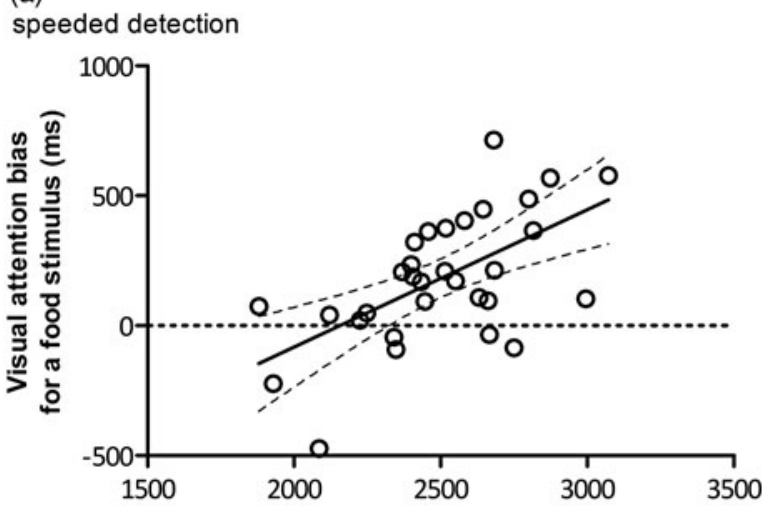

delayed detection

Reported food intake (kCal/day)

(b)

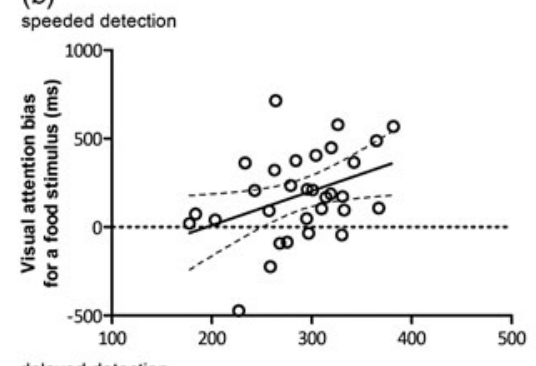

delayed detection

Reported carbohydrate intake (gram/day) (c)

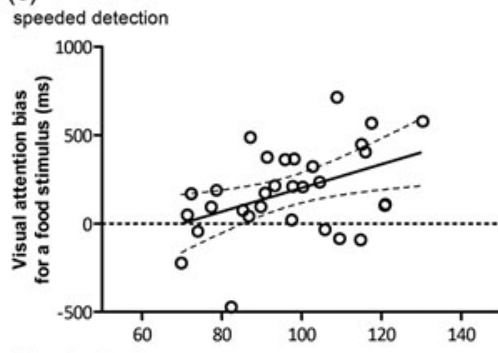

delayed detection

Reported protein intake (gram/day) (d)

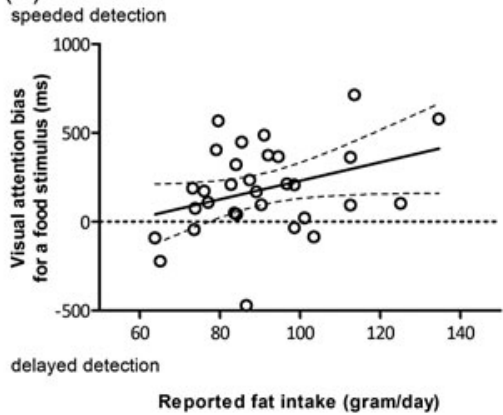

Fig. 1. Correlation of visual attention for food stimulus with (a) reported total food intake, $(b)$ reported carbohydrate intake, (c) reported protein intake, and $(d)$ reported fat intake.

(a)

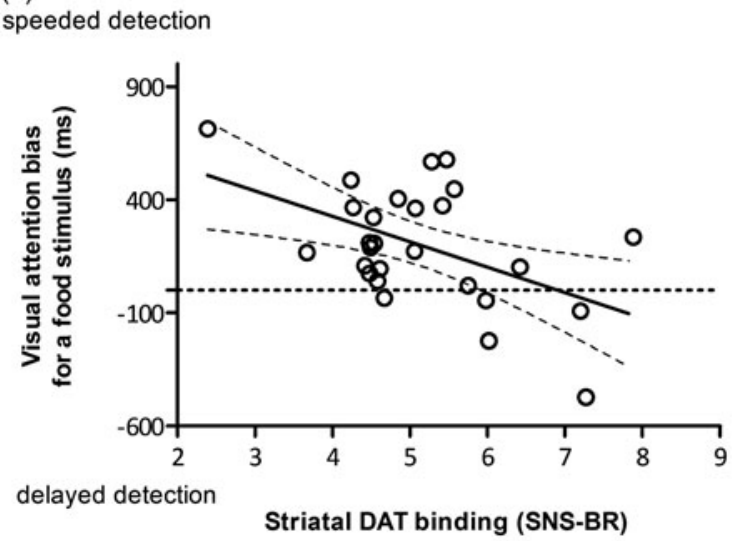

(b)

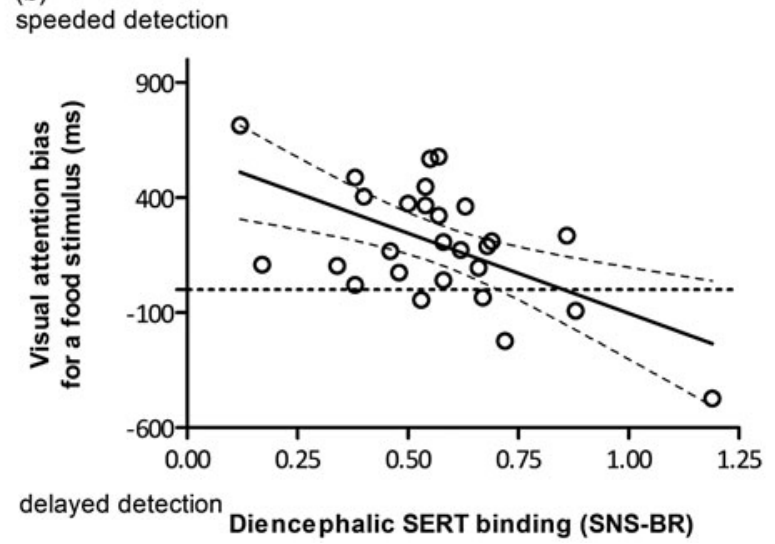

Fig. 2. Correlation of detection speed of a visual food stimulus with (a) striatal dopamine transporter (DAT) binding and $(b)$ diencephalon serotonin transporter (SERT) binding. SNS-BR, Specific to non-specific binding ratio.

humans, although data on visual attention bias in obesity are inconclusive (Werthmann et al. 2014a).

The role of DA in food intake and body-weight regulation has convincingly been shown (Volkow et al. 2011). In obese humans striatal $D^{D A} D_{2 / 3}$ receptor binding is decreased (de Weijer et al. 2011; van de Giessen et al. 2014), but no relationship between striatal DA transporter binding and obesity has been demonstrated (Thomsen et al. 2012; van de Giessen et al. 2013). Nevertheless, our data suggest that striatal DAT clearly correlates with the visual attention bias for food but only with a tendency for a correlation with BMI. Thus, regulation of striatal synaptic DA levels by DAT may not be the major component of the 
dopaminergic system that is related to body-weight regulation but it does relate to attention bias for food. It is likely that additional factors are involved in DA's role in body-weight regulation, for example, via regulation of post-synaptic $\mathrm{DA}_{2 / 3}$ receptor signaling; however, this remains to be investigated.

Interpretation of our data should be made with caution since it is unknown how imaging data on DAT binding can be translated to extracellular DA levels, although rodent data indicate that high DAT binding corresponds with high extracellular DA levels. Mice in which DAT expression is genetically downregulated to $10 \%$ of expression levels of wild-type mice increased extracellular DA concentrations in the striatum and hypothalamus (Zhuang et al. 2001; Beeler et al. 2012), and thus lower DAT binding could reflect higher available extracellular concentrations of DA. Interestingly, the mice with lower DAT (and thus higher extracellular DA) show higher intake when the cost for food was increased reflecting higher motivation and willingness to work for food (Beeler et al. 2012). In addition, upon striatal DA depletion animals do not feed at all demonstrating that DA is essential for motivation for food in general (Palmiter, 2008). Translating these data from rodents to the findings in our lean subjects suggest that speeded detection of food pictures could reflect higher motivation for food through higher striatal DA. Although this is in line with lower DAT binding reflecting higher extracellular DA in DAT knockdown mice, other studies show a reduction in striatal DAT binding after long-term systemic DA depletion (Kilbourn et al. 1992; Gordon et al. 1996), making it difficult to draw firm conclusions on how DAT binding and visual attention bias relate to striatal extracellular DA concentrations.

For diencephalic SERT binding, too, lower SERT binding could reflect higher or lower extracellular 5-HT levels. SERT knockout mice have increased striatal extracellular 5-HT and greater depolarizationinduced increases in striatal 5-HT (Mathews et al. 2004), as well as reduced food intake (Chen et al. 2012). In line, short-term inhibition of SERT with selective serotonin reuptake inhibitors (SSRIs) results in reduced food intake (Halford et al. 2007); however, long-term SSRI use results in body-weight (re)gain (Fava et al. 2000; Raeder et al. 2006). It has also been shown that, in obesity, representing a chronic state of excessive food intake and potentially a high attention for food (Castellanos et al. 2009; Tetley et al. 2009; Nijs et al. 2010), SERT binding is reduced (Erritzoe et al. 2010; Borgers et al. 2014) suggesting that chronically low SERT availability is associated with decreased extracellular 5-HT. Moreover, 2 weeks of tryptophan (and thus 5-HT) depletion in rats results in lower SERT binding (Rattray et al. 1996). In summary, most data point towards lower SERT binding reflecting reduced 5-HT signaling, yet this remains speculative and further mechanistic studies in rodents are needed to elucidate the relationship between SERT (and also DAT) binding and extracellular neurotransmitter concentrations under different conditions. We measured SERT binding in the diencephalon, a region that holds several SERT-rich brain structures such as the hypothalamus, thalamus and pineal gland. Due to limitations in resolution of the SPECT scanner in the current study we were not able to narrow the correlation with visual attention bias to a specific diencephalic region.

In addition to demonstrating relationships between brain SERT and DAT binding and food detection speed, we also demonstrate that food detection speed is independently associated with reported food intake. The correlation is the strongest for total caloric intake, but the three main macronutrients (fat, carbohydrates and protein) also positively correlate with visual attention bias for food. Werthmann et al. showed that a high visual attention bias for chocolate is related to higher chocolate intake (Werthmann et al. 2014a), but to our knowledge we are the first to show a more general relationship between food detection speed and reported food intake.

We did not find significant correlations between BMI and SERT or DAT binding, although the correlation with striatal DAT binding showed a trend. The lack of correlation between BMI and SERT is in contrast to a previous study demonstrating correlations between BMI and SERT binding in humans (Wang et al. 2001; Erritzoe et al. 2010); however, these studies included subjects with a wide range of BMI whereas all our subjects were lean. The tendency of a correlation between DAT and BMI is in line with our previous reported tendency of a correlation between fat mass and lean mass with DAT binding in healthy lean man (Koopman et al. 2014b); however, striatal DAT binding did not correlate with BMI when this was measured in a larger cohort with a wider range of BMI (Thomsen et al. 2012; van de Giessen et al. 2013). Overall, it might well be that BMI is not an optimal measure of body composition, athletes for example have a higher BMI due to increased muscle mass and not fat mass (Rothman, 2008) making comparisons between correlations with BMI over a wider range or in lean subjects more difficult.

Our experiments were performed in fasted subjects. Previous research suggests that fasted subjects respond faster to visual food stimuli compared to sated subjects, regardless of being overweight/obese or not (Castellanos et al. 2009; Nijs et al. 2010). It would be of interest to include the effect of a meal as a variable in future studies on visual attention bias in humans. 
In conclusion, we show that striatal DAT binding and diencephalic SERT binding negatively correlate with visual attention bias for food in non-obese, healthy conditions, in line with a key role for DA and 5-HT in the regulation of feeding behavior. At present it is unknown how SERT and DAT binding in imaging studies under fasting conditions relate to extracellular concentrations of 5-HT and DA, respectively. Therefore further experimental studies are needed to elucidate their respective roles in feeding behavior in humans. In addition, changes in SERT and striatal DAT might predispose to disturbed feeding behavior and might be a target for eating disorders, obesity included.

\section{Supplementary material}

For supplementary material accompanying this paper visit http://dx.doi.org/10.1017/S0033291716000222.

\section{Acknowledgements}

The study was funded by a Ph.D. fellowship grant awarded by the executive board of the Academic Medical Center Amsterdam, there were no other sources of funding. We acknowledge L. S. Wolbert and E. M. van de Giessen for their assistance with the computer tasks and questionnaires.

\section{Declaration of Interest}

J.B. is a consultant at GE Healthcare. The remaining authors have no conflict of interest.

\section{References}

Baldo BA, Sadeghian K, Basso AM, Kelley AE (2002). Effects of selective dopamine D1 or D2 receptor blockade within nucleus accumbens subregions on ingestive behavior and associated motor activity. Behavioural Brain Research 137, 165-177.

Beeler JA, Frazier CR, Zhuang X (2012). Dopaminergic enhancement of local food-seeking is under global homeostatic control. European Journal of Neuroscience 35, 146-159.

Berridge KC (2007). The debate over dopamine's role in reward: the case for incentive salience. Psychopharmacology 191, 391-431.

Berridge KC (2009). 'Liking' and 'wanting' food rewards: brain substrates and roles in eating disorders. Physiololgy and Behavior 97, 537-550.

Booij J, Hemelaar TG, Speelman JD, de BK, Janssen AG, van Royen EA (1999). One-day protocol for imaging of the nigrostriatal dopaminergic pathway in Parkinson's disease by [ ${ }^{123}$ I]FPCIT SPECT. Journal of Nuclear Medicine 40, 753-761.

Borgers AJ, Koopman KE, Bisschop PH, Serlie MJ, Swaab DF, Fliers E, la Fleur SE, Alkemade A (2014). Decreased serotonin transporter immunoreactivity in the human hypothalamic infundibular nucleus of overweight subjects. Frontiers in Neuroscience 8, 106.

Breisch ST, Zemlan FP, Hoebel BG (1976). Hyperphagia and obesity following serotonin depletion by intraventricular p-chlorophenylalanine. Science 192, 382-385.

Castellanos EH, Charboneau E, Dietrich MS, Park S, Bradley BP, Mogg K, Cowan RL (2009). Obese adults have visual attention bias for food cue images: evidence for altered reward system function. International Journal of Obesity 33, 1063-1073.

Chen X, Margolis KJ, Gershon MD, Schwartz GJ, Sze JY (2012). Reduced serotonin reuptake transporter (SERT) function causes insulin resistance and hepatic steatosis independent of food intake. PLoS ONE 7, e32511.

Daws LC, Gould GG (2011). Ontogeny and regulation of the serotonin transporter: providing insights into human disorders. Pharmacology \& Therapeutics 131, 61-79.

de Weijer BA, van de Giessen E, van Amelsvoort TA, Boot E, Braak B, Janssen IM, van de Laar A, Fliers E, Serlie MJ, Booij J (2011). Lower striatal dopamine D2/3 receptor availability in obese compared with non-obese subjects. EJNMMI Research 1, 37.

Derryberry D (1989). Effects of goal-related motivational states on the orienting of spatial attention. Acta Psychologica 72, 199-220.

Erritzoe D, Frokjaer VG, Haahr MT, Kalbitzer J, Svarer C, Holst KK, Hansen DL, Jernigan TL, Lehel S, Knudsen GM (2010). Cerebral serotonin transporter binding is inversely related to body mass index. Neuroimage 52, 284-289.

Fairburn CG, Beglin SJ (1994). Assessment of eating disorders: interview or self-report questionnaire? International Journal of Eating Disorders 16, 363-370.

Fava M, Judge R, Hoog SL, Nilsson ME, Koke SC (2000). Fluoxetine versus sertraline and paroxetine in major depressive disorder: changes in weight with long-term treatment. Journal of Clinical Psychiatry 61, 863-867.

Field M, Cox WM (2008). Attentional bias in addictive behaviors: a review of its development, causes, and consequences. Drug Alcohol Dependence 97, 1-20.

Field M, Munafo MR, Franken IH (2009). A meta-analytic investigation of the relationship between attentional bias and subjective craving in substance abuse. Psychological Bulletin 135, 589-607.

German CL, Baladi MG, McFadden LM, Hanson GR, Fleckenstein AE (2015). Regulation of the dopamine and vesicular monoamine transporters: pharmacological targets and implications for disease. Pharmacological Reviews 67, 1005-24.

Gordon I, Weizman R, Rehavi M (1996). Modulatory effect of agents active in the presynaptic dopaminergic system on the striatal dopamine transporter. European Journal of Pharmacology 298, 27-30.

Haider S, Haleem DJ (2000). Decreases of brain serotonin following a food restriction schedule of 4 weeks in male and female rats. Medical Science Monitor 6, 1061-1067.

Halford JC, Harrold JA, Boyland EJ, Lawton CL, Blundell JE (2007). Serotonergic drugs : effects on appetite 
expression and use for the treatment of obesity. Drugs 67 , 27-55.

Hardman CA, Scott J, Field M, Jones A (2014). To eat or not to eat. The effects of expectancy on reactivity to food cues. Appetite 76, 153-160.

Kelley AE, Baldo BA, Pratt WE, Will MJ (2005).

Corticostriatal-hypothalamic circuitry and food motivation: integration of energy, action and reward. Physiology and Behavior 86, 773-795.

Kilbourn MR, Sherman PS, Pisani T (1992). Repeated reserpine administration reduces in vivo [18F]GBR 13119 binding to the dopamine uptake site. European Journal of Pharmacology 216, 109-112.

Koopman KE, Booij J, Fliers E, Serlie MJ, la Fleur SE (2013). Diet-induced changes in the Lean Brain: Hypercaloric high-fat-high-sugar snacking decreases serotonin transporters in the human hypothalamic region. Molecular Metabolism 2, 417-422.

Koopman KE, Caan MW, Nederveen AJ, Pels A, Ackermans MT, Fliers E, la Fleur SE, Serlie MJ (2014a). Hypercaloric diets with increased meal frequency, but not meal size, increase intrahepatic triglycerides: a randomized controlled trial. Hepatology 60, 545-553.

Koopman KE, la Fleur SE, Fliers E, Serlie MJ, Booij J (2012). Assessing the optimal time point for the measurement of extrastriatal serotonin transporter binding with 123I-FP-CIT SPECT in healthy, male subjects. Journal of Nuclear Medicine 53, 1087-1090.

Koopman KE, Roefs A, Elbers C, Fliers E, Booij J, Serlie MJ, la Fleur SE (2014b). Striatal dopamine transporter binding correlates with body composition, energy expenditure, and visual attention bias for food-related cues. Diabetes 63, A519.

Kuikka JT, Tammela L, Karhunen L, Rissanen A, Bergstrom KA, Naukkarinen H, Vanninen E, Karhu J, Lappalainen R, Repo-Tiihonen E, Tiihonen J, Uusitupa M (2001). Reduced serotonin transporter binding in binge eating women. Psychopharmacology 155, 310-314.

Lam DD, Heisler LK (2007). Serotonin and energy balance: molecular mechanisms and implications for type 2 diabetes. Expert Reviews in Molecular Medicine 9, 1-24.

Luce KH, Crowther JH (1999). The reliability of the eating disorder examination-self-report questionnaire version (EDE-Q). International Journal of Eating Disorders 25, 349-351.

Mathews TA, Fedele DE, Coppelli FM, Avila AM, Murphy DL, Andrews AM (2004). Gene dose-dependent alterations in extraneuronal serotonin but not dopamine in mice with reduced serotonin transporter expression. Journal of Neuroscience Methods 140, 169-181.

Myerson J, Green L, Warusawitharana M (2001). Area under the curve as a measure of discounting. Journal of the Experimental Analysis of Behavior 76, 235-243.

Nijs IM, Franken IH, Muris P (2007). The modified trait and state food-cravings questionnaires: development and validation of a general index of food craving. Appetite 49, 38-46.

Nijs IM, Muris P, Euser AS, Franken IH (2010). Differences in attention to food and food intake between overweight/ obese and normal-weight females under conditions of hunger and satiety. Appetite 54, 243-254.
Palmiter RD (2008). Dopamine signaling in the dorsal striatum is essential for motivated behaviors: lessons from dopamine-deficient mice. Annals of the New York Academy of Sciences 1129, 35-46.

Patton JH, Stanford MS, Barratt ES (1995). Factor structure of the Barratt impulsiveness scale. Journal of Clinical Psychology 51, 768-774.

Raeder MB, Bjelland I, Emil VS, Steen VM (2006). Obesity, dyslipidemia, and diabetes with selective serotonin reuptake inhibitors: the hordaland health study. Journal of Clinical Psychiatry 67, 1974-1982.

Rattray M, Baldessari S, Gobbi M, Mennini T, Samanin R, Bendotti C (1996). p-Chlorphenylalanine changes serotonin transporter mRNA levels and expression of the gene product. Journal of Neurochemistry 67, 463-472.

Rothman KJ (2008). BMI-related errors in the measurement of obesity. International Journal of Obesity 32 (Suppl. 3), S56-S59.

Saller CF, Stricker EM (1976). Hyperphagia and increased growth in rats after intraventricular injection of 5,7-dihydroxytryptamine. Science 192, 385-387.

Schag K, Schonleber J, Teufel M, Zipfel S, Giel KE (2013). Food-related impulsivity in obesity and binge eating disorder-a systematic review. Obesity Reviews 14, 477-495.

Small DM, Jones-Gotman M, Dagher A (2003). Feeding-induced dopamine release in dorsal striatum correlates with meal pleasantness ratings in healthy human volunteers. Neuroimage 19, 1709-1715.

Smith SR, Weissman NJ, Anderson CM, Sanchez M, Chuang E, Stubbe S, Bays H, Shanahan WR (2010). Multicenter, placebo-controlled trial of lorcaserin for weight management. New England Journal of Medicine 363, 245-256.

Tetley A, Brunstrom J, Griffiths P (2009). Individual differences in food-cue reactivity. The role of BMI and everyday portion-size selections. Appetite 52, 614-620.

Thomsen G, Ziebell M, Jensen PS, da Cuhna-Bang S, Knudsen GM, Pinborg LH (2012). No correlation between body mass index and striatal dopamine transporter availability in healthy volunteers using SPECT and [I]PE2I. Obesity 21, 1803-1806.

Tindell AJ, Berridge KC, Zhang J, Pecina S, Aldridge JW (2005). Ventral pallidal neurons code incentive motivation: amplification by mesolimbic sensitization and amphetamine. European Journal of Neuroscience 22, 2617-2634.

van de Giessen E, Celik F, Schweitzer DH, van den Brink W, Booij J (2014). Dopamine D2/3 receptor availability and amphetamine-induced dopamine release in obesity. Journal of Psychopharmacology 28, 866-873.

van de Giessen E, Hesse S, Caan MW, Zientek F, Dickson JC, Tossici-Bolt L, Sera T, Asenbaum S, Guignard R, Akdemir UO, Knudsen GM, Nobili F, Pagani M, Vander BT, Van LK, Varrone A, Tatsch K, Booij J, Sabri O (2013). No association between striatal dopamine transporter binding and body mass index: a multi-center European study in healthy volunteers. Neuroimage 64, 61-67. van Strien T, Frijters JE, Bergers GP, Defares PB (1986). Dutch eating behaviour questionnaire for assessment of 
restrained, emotional and external eating behaviour. International Journal of Eating Disorders 5, 295-315.

Volkow ND, Wang GJ, Baler RD (2011). Reward, dopamine and the control of food intake: implications for obesity. Trends Cognitive Sciences 15, 37-46.

Waldbillig RJ, Bartness TJ, Stanley BG (1981). Increased food intake, body weight, and adiposity in rats after regional neurochemical depletion of serotonin. Journal of Comparative and Physiological Psychology 95, 391-405.

Wang GJ, Volkow ND, Logan J, Pappas NR, Wong CT, Zhu W, Netusil N, Fowler JS (2001). Brain dopamine and obesity. Lancet 357, 354-357.

Werthmann J, Field M, Roefs A, Nederkoorn C, Jansen A (2014a). Attention bias for chocolate increases chocolate consumption-an attention bias modification study. Journal of Behavior Therapy and Experimental Psychiatry 45, 136-143.
Werthmann J, Renner F, Roefs A, Huibers MJ, Plumanns L, Krott N, Jansen A (2014b). Looking at food in sad mood: do attention biases lead emotional eaters into overeating after a negative mood induction? Eating Behaviors 15, 230-236.

Werthmann J, Roefs A, Nederkoorn C, Jansen A (2013). Desire lies in the eyes: attention bias for chocolate is related to craving and self-endorsed eating permission. Appetite 70, 81-89.

Wittmann M, Leland DS, Paulus MP (2007). Time and decision making: differential contribution of the posterior insular cortex and the striatum during a delay discounting task. Experimental Brain Research 179, 643-653.

Zhuang X, Oosting RS, Jones SR, Gainetdinov RR, Miller GW, Caron MG, Hen R (2001). Hyperactivity and impaired response habituation in hyperdopaminergic mice. Proceedings of the National Academy of Sciences USA 98, 1982-1987. 